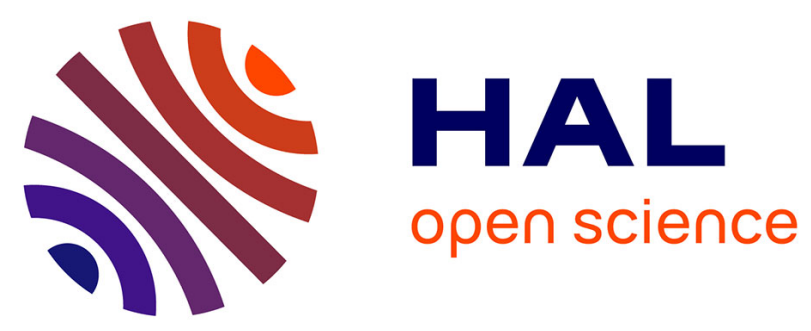

\title{
Microbialites and microbial communities: Biological diversity, biogeochemical functioning, diagenetic processes, tracers of environmental changes \\ Gilbert Camoin, Pascale Gautret
}

\section{- To cite this version:}

Gilbert Camoin, Pascale Gautret. Microbialites and microbial communities: Biological diversity, biogeochemical functioning, diagenetic processes, tracers of environmental changes. Sedimentary Geology, 2006, 185, pp.127-130. 10.1016/j.sedgeo.2005.12.007 · hal-00091718

\section{HAL Id: hal-00091718 \\ https://hal-insu.archives-ouvertes.fr/hal-00091718}

Submitted on 28 Sep 2006

HAL is a multi-disciplinary open access archive for the deposit and dissemination of scientific research documents, whether they are published or not. The documents may come from teaching and research institutions in France or abroad, or from public or private research centers.
L'archive ouverte pluridisciplinaire HAL, est destinée au dépôt et à la diffusion de documents scientifiques de niveau recherche, publiés ou non, émanant des établissements d'enseignement et de recherche français ou étrangers, des laboratoires publics ou privés. 


\title{
Microbialites and microbial communities: Biological diversity, biogeochemical functioning, diagenetic processes, tracers of environmental changes
}

\author{
G.F. Camoin ${ }^{\mathrm{a},}$ and P. Gautret ${ }^{\mathrm{b}}$ \\ ${ }^{a}$ CEREGE, Europe de l'Arbois, B.P. 80 F-Aix-en Provence, France \\ ${ }^{\mathrm{b}}$ ISTO, UMR6113 Orléans, France
}

\section{Introduction}

This special issue is dedicated to microbialites and microbial communities and addresses their biological diversity, their biogeochemical functioning, their roles in diagenetic processes and their environmental significance. It is the logical successor of the special issue that one of us edited after the workshop on "Microbial mediation in carbonate diagenesis" which was held in Chichilianne (France) in 1997 (Camoin, G., Ed., 1999. Microbial mediation in carbonate diagenesis. Sedim. Geol., 126, 1-334).

The following set of papers arose from a multidisciplinary international workshop entitled "Microbialites and microbial communities in sedimentary systems: biological diversity, biogeochemical functioning, diagenetic processes, tracers of environmental changes" that was held in Paris, France, in September 2004 (G. Camoin and P. Gautret, convenors). This meeting was sponsored by the French Geological Society (Société Géologique de France, SGF), the French Association of Sedimentologists (Association des Sédimentologistes Français, ASF) and the French National Program on Coastal Environments (Programme National Environnement Côtier, PNEC).

The goals of this Workshop were: 1) to review the knowledge concerning modern and fossil microbial communities and microbialites that occur in various sedimentary environments (marine realm, thermal springs, lakes, rivers, deserts, karsts etc.), and 2) to establish a prospective regarding the research activities to be developed in various fields concerning the study of microbial communities and microbialites: their biological diversity, their biogeochemical functioning, their implication in the cycles of elements, the diagenetic processes that characterize these structures and the control exerted by environmental and climatic parameters both on their composition and their distribution in time and space.

This Workshop has been attended by 70 participants from 11 countries (Belgium, France, Germany, United States, Hungary, Ireland, Italy, The Netherlands, Poland, Switzerland and United Kingdom) with diverse specialities (sedimentology, geochemistry, biology, biochemistry, oceanography, microbiology) and research interests (from Precambrian to modern environments and from natural settings to laboratory experimentation).

52 talks and several open discussions concerned the following interrelated topics, among many, on microbialites : their biological diversity, their biogeochemical functioning, their growth patterns and development, their environmental significance, and the microbial diagenesis and diagenetic processes in microbialites. 
The abstracts were assembled in a Special Publication of the Association of French Sedimentologists (Camoin and Gautret, Eds, 2004. Microbialites and microbial communities in sedimentary systems, A.S.F. Sp. Publ., 46).

\section{Summary of contents}

The present volume includes a selection of papers arising from oral contributions presented during the Workshop and covering many aspects of the current research on microbial communities and microbialites.

The papers are grouped in two sections: 1) microbial communities: diagenetic processes, biogeochemical functioning and biological diversity, and 2) microbialites over geological time: tracers of environmental changes.

\subsection{Microbial communities: biological diversity, biogeochemical functioning and diagenetic processes}

\subsubsection{Sulfate reducing bacteria in microbial mats: changing paradigms, new discoveries (L.K. Baumgartner, R.P. Reid, C. Dupraz, A.W. Decho, D.H. Buckley, J.R. Spear, K.M. Przekop and P. T. Visscher)}

In this paper, Baumgartner et al. review recent research on the distribution of sulfate-reducing bacteria and present new preliminary findings on the diversity and distribution of $\delta$ proteobacterial sulfate-reducing bacteria in lithifying and non-lithifying microbial mat systems. They also discuss the mechanisms for carbonate precipitation via sulfate reduction. They conclude that sulfate-reducing bacteria are much more diverse than previously thought and demonstrate the close microspatial association of such bacteria and cyanobacteria in the oxic zone of the mat.

\subsubsection{Iron-bacterial mediation in Phanerozoic red limestones: state of the art (B. Mamet and A. Préat)}

Mamet and Préat investigate the origin of the red pigmentation in Phanerozoic limestones from various ages and depositional settings, and discuss the three different pathways that could be proposed to explain this pigmentation, namely a telogenetic alteration, a detrital input and the role of iron-bacteria. Based on a coupled sedimentological, mineralogical and geochemical (iron isotope analysis) study, they conclude that the red pigmentation is neither linked to alteration or contamination, nor to a detrital origin. They favour a microbially mediated origin of the red pigmentation related to the activity of iron-bacteria that thrived in the superficial part of the unconsolidated sediment where various microaerophilic environments were produced by dysoxic-anoxic interfaces.

2.1.3. Lower Eocene carbonate chimneys (Varna, NE Bulgaria): formation mechanisms and the (a)biological mediation of chimney growth? (E. De Boever, R. Swennen and L. Dimitrov)

De Boever et al. document the occurrence of massive carbonate cemented columns (chimneys) and horizontal interbeds within loose Lower Eocene sands from the Pobiti Kamani area (Varna, northeast Bulgaria). Petrographical and stable isotope analyzes reveal a 
relationship between these structures and processes of fossil hydrocarbon seepage involving mixing conditions between two fluid end members: (1) a methane- and/or higher hydrocarbon-derived carbon member and (2) a member with less contribution of methane. Geochemical data suggest that the venting system was not a true "cold seep" but resulted from a leakage of a single fluid source at depth during Lower Eocene times. The authors identified only few petrographical evidences of possible ancient microbial activity involved in carbon cycling and calcite precipitation typical of cold seep settings and note that this may result from the diagenetic alteration of organic components.

\subsubsection{Lithifying microbial mats in Lagoa Vermelha, Brazil: modern Precambrian relics? (C. Vasconcelos, R. Warthmann, J. A. McKenzie, P.T. Visscher and Y. van Lith)}

Vasconcelos et al. studied bacterial populations and microbially-mediated precipitation processes in microbial mats and the underlying sediment from the Lagoa Vermelha, Brazil, in order to define the boundary conditions responsible for the formation of high Mg-calcite and dolomite. Their results show that high Mg-calcite precipitates in the top layers of the microbial mat where oxygenic photosynthesis and aerobic respiration prevail, while mat sulfide oxidation and sulfate reduction induce an increasing formation of $\mathrm{Mg}$ carbonates in anoxic layers. Because comparable environmental (e.g., chemical) conditions and similar microbial communities have been probably common in the Precambrian, they conclude that microbial carbonate as a biomineral could be a record of metabolism throughout geological time.

\subsubsection{Rrh: simulation of stromatolite morphospace (C. Dupraz, R. Pattisina and E.P. Verrecchia)}

Dupraz et al. investigate the morphology of stromatolites, explore the stromatolite morphological space, and reconstruct the intrinsic and extrinsic factors responsible for natural stromatolite morphogenesis by combining Diffusion Limited Aggregation (DLA) and cellular automata (CA). A holistic approach is used in this study because interaction between intrinsic and extrinsic factors (e.g., energy, nutrients, sedimentation etc.) that progressively shapes the final stromatolite morphology can neither be easily described by simple mathematical equations, nor by simple physical laws or chemical reactions. The virtual morphologies obtained are then compared to their natural counterpart. The authors demonstrate that Precambrian stromatolite morphologies that cannot be produced with numerical modeling such as the KPZ equation can be simulated with the DLA-CA model, involving a minimum set of variables.

\subsubsection{Plausible mechanisms for the boring on carbonates by microbial phototrophs ( $F$. Garcia-Pichel)}

Garcia-Pichel's paper concerns the mechanisms by which photosynthetic microbes, particularly cyanobacteria, are able to bore into carbonates, thus playing a major role in the destruction of biogenic carbonates and coastal limestones, the reworking of carbonate sands and the cementation of microbialites. He points out that excavation by acidulation, commonly thought to be a possible mechanism, constitutes an apparent paradox. Accordingly, he proposes three alternative mechanistic models based on either temporal or spatial separation of photosynthesis and respiration, and on the active extrusion of calcium ions through an active cellular uptake and transport process. From the three models presented, the latter is shown to be most appropriate in describing and explaining the boring phenomenon. 
2.1.7. Biogeological signatures of microboring cyanobacterial communities in marine carbonates from Cabo Rojo, Puerto Rico (E. Chacón, E. Berrendero and F. GarciaPichel)

This second paper on boring organisms is presented by Chacon et al. who document an evaluation of euendolithic cyanobacterial assemblages from a variety of marine carbonate substrates. They use a polyphasic approach including electron microscopy, cultivation, and molecular genetic techniques in order to avoid limitations and biases that those different methods introduce when they are used independently. The authors show that communities of boring organisms are much more complex in hard substrates than in soft substrates. However, they conclude that the geological and sedimentary imprints of the boring community are uniform regardless of the nature of the substrate, suggesting that the mechanism of action is common and most likely universal.

\subsection{Microbialites over geological time: tracers of environmental changes}

\subsubsection{Microbial carbonate abundance compared with fluctuations in metazoan diversity over geological time (R. Riding)}

Riding summarizes the secular variation in microbial carbonate abundance over the past 3000 Myr that can be reflected by stromatolite morphotype diversity and reefal microbial carbonate abundance. The general shape of the relevant curve displays a peak of abundance $1250 \mathrm{Myr}$ ago, a Late Proterozoic decline, a Cambrian resurgence, and then a fluctuating decline during the remainder of the Phanerozoic. Riding discusses the possible causes for the fluctuations observed and parallelizes especially the inception of stromatolite decline $1250 \mathrm{Myr}$ ago with the Proterozoic metazoan diversification. However, he points out that failure of microbial carbonates to increase in the aftermaths of the End-Ordovician, End-Triassic and EndCretaceous Mass Extinctions suggests that other factors have significantly influenced longterm changes in microbial carbonate abundance.

\subsubsection{Calcimicrobial stromatolites at the Permian-Triassic boundary in a western Tethyan section, Bükk Mountains, Hungary (K. Hips and J. Haas)}

Hips and Haas document the development of a stromatolite unit in an open marine environment during the Early Triassic (Gerennavár Formation; Bükk Mountains, Northern Hungary). They illustrate well preserved microstructures in stromatolite beds that include sphere clusters in dense micrite groundmass, bushy aggregates of micrite clots, bundles of prostrate threads, and peloids. Hips and Haas assume that those microstructures were produced through the early lithification of microbial fabrics (e.g., coccoid-cyanobacteria mats, tufted clusters similar to Angusticellularia, and filamentous bundles) as a result of significant changes in seawater chemistry during Late Permian-Early Triassic time interval.

\subsubsection{Microbial crusts as indicators of stratigraphic diastems in the Cambrian Brèche à Micmacca, Atlas Mountains of Morocco (J. J. Álvaro and S. Clausen)}

In this paper, Alvaro and Clausen illustrate the in situ formation of microbial crusts during periods of very low rates of deposition or non-deposition of high-energy clastic sediments on carbonate and mixed (carbonate-siliciclastic) Cambrian platforms from the Atlas Mountains (Morocco). They show that the microbial mats appear to have been restricted to specific microenvironmental conditions, episodically developed on irregular substrates of reduced 
clastic influence. Environmental changes that induced this localized and episodic microbial colonization probably included a decrease in sedimentation rates and water energy, a reduction in siliciclastic supply, or a combination of these. They conclude that the growth of microbial mats can be used as a record of time interrupting background-sedimentation patterns characterized by the amalgamation of high-energy events.

2.2.4. Syndepositional cements associated with nannofossils in the Marmolada Massif: evidences of microbially mediated primary marine cements? (Middle Triassic, Dolomites, Italy) (F. Russo, P. Gautret, A. Mastandrea, E. Perri)

Russo et al. studied the globose masses of fibrous calcite cements ("evinosponges") that occur in the Triassic platform carbonates from the Marmolada (Italy). They report geochemical data (Sr content) suggesting that these cements result from the neomorphic replacement of an aragonitic precursor. They discuss the origin of the alternations of bright and dark bands revealed by epifluorescence analyses and interpret the spherical bodies occurring in bright bands as nannobacterial cells and the dark bands as remains of organic matter. The authors conclude that the formation of the "evinosponges" could have been mediated through microbial activity.

2.2.5. Environmental significance of microbialites in reef environments during the last deglaciation (G.F. Camoin, G. Cabioch, A. Eisenhauer, J.-C. Braga, B. Hamelin and G. Lericolais)

In their paper, Camoin et al. document the development of microbialites in reef rocks from the Last Deglaciation (23000 to 6000 yr B.P.) dredged on modern fore-reef slopes of Tahiti and the Marquesas islands (French Polynesia). They show that microbialites formed either in shallow-water settings ("reefal microbialites") or in deeper water environments ("slope microbialites"), suggesting that they played a prominent role in reef sequences during the last deglacial sea level rise. The authors conclude that the development of microbialites characterizes periods of environmental degradation (e.g., increased alkalinity and nutrient availability) consequential on the rapid sea-level rise and abrupt climatic changes of that time.

2.2.6. Contribution of microbialites to the development of coral reefs during the last deglacial period: case study from Vanuatu (South-West Pacific) (G. Cabioch, G.F. Camoin, G.E. Webb, F. Le Cornec, M. Garcia Molina, C. Pierre, M. M. Joachimski)

This study by Cabioch et al. concerns the same time window than the previous paper, the Last Deglaciation, and is based on a comparative study of two neighbouring areas (Tasmaloum and Urélapa) having much different mean uplift rates and environmental settings. The authors propose therefore an analysis of the environmental factors that promoted the widespread development of microbialite crusts in reef sequences from the island of Espiritu Santo (Vanuatu). Nutrient supplies (terrigenous fluxes and upwelling), coupled with very rapid rise in sea level, are seen as the major causes of the distinctive distribution of microbialites in reef cores from the two studied areas.

\subsubsection{Growth morphologies of modern marine stromatolites: a case study from Highborne Cay, Bahamas (M. S. Andres and R. P. Reid)}

In their paper, Andres and Reid document the occurrence of stromatolite columns and ridges in various modern Bahamian sites and explore the relative contributions of physical and 
biological environmental factors controlling stromatolite morphologies. Their results suggest that growth morphologies on a macro scale are related to an intricate relationship between accommodation space, sediment supply, and hydrodynamics. The stromatolite structure may be obscured or even destroyed through the colonization of stromatolites by macroalgae and boring organisms.

\section{Acknowledgements}

This special issue has benefited from the help of so many colleagues who have acted as referees: G. Arp, S. Awramik, B. Jones, D. Birgel, M. Boettcher, C.J.R. Braithwaite, R. Burne, C. Perry, H. Chafetz, P. Clari, C. Dupraz, C. Gaillard, F. Garcia-Pichel, G. Gerdes, S. Golubic, A. Knoll, K. Kolo, W.E. Krumbein, R. Leinfelder, R. Marinelli, B. Pratt, P. Reid, R. Riding, F. Taylor, V. Thiel, J. Thompson, C. Vasconcelos, E. Verrechia, G. Webb, A. Wilmotte and R. Wood.

As editors, we would like to thank warmly all these referees whose collaboration ensures the high quality of this volume.

Finally, we extend our thanks to the Elsevier staff, especially Tonny Smit, for their encouragement and help in the edition of this special issue. 